\title{
Genetical Crossbreeding Effect on the Zootechnical Performances of the Domestic Rabbit (Algeria) $x$ Californian
}

\author{
Mefti Korteby Hakima ${ }^{1}$, Kaidi Rachid ${ }^{2}$, Sid Sihem ${ }^{3}$, Boukhelifa Ahmed ${ }^{1}$, Derradji Billel ${ }^{1}$, Kenchache Youcef $^{1}$ and \\ Mareche Hachemi ${ }^{1}$ \\ 1. Department of agronomy science (Animal production), Saad Dhlablab University, Blida 09100, Algeria \\ 2. Department of veterinary science, Saad Dahlab University, Blida 09100, Algeria \\ 3. National Agronomy Institute, Algiers 16010, Algeria
}

Received: August 04, 2012 / Accepted: December 03, 2012 / Published: February 28, 2013.

\begin{abstract}
The carried out experimental work aimed at the improvement of the native rabbit zootechnical performances. The goal was to run a genetical progress of an exotic breed "the Californian" through a crossbreeding with a native rabbit. Ten females have been crossed with two native males $(\mathrm{L} \times \mathrm{C})$ compared to controls Native $\times$ Native $(\mathrm{N} \times \mathrm{N})$ and Californian $\times$ Californian $(\mathrm{C} \times \mathrm{C})$. The reproduction and growth performances are clearly improved by crossbreeding effect, the recorded heterosis are:

- $\quad 9.43 \%, 16.34 \%$ and $21.93 \%$, respectively for the alive litter size, alive and weaned;

- $10 \%, 16.75 \%$ and $2.57 \%$, respectively for the alive litter weight, alive and weaned;

- $2.57 \%$ for the individual weight at birth;

- $\quad 10 \%$ and $7 \%$ for post weaning performances, respectively day mean gains and feed conversion ratio.

Weight at slaughter is improved with $167 \mathrm{~g}$, which representing a considerable level for the native population. Genetic crossbreeding between the Algerian native rabbit and the Californian, raised under rearing conditions of the Blida university farm experiment showed its efficiency on the most zootechnical performances. The complementary effect turned up positively on the crossbred rabbits. Their post-weaning growth performance is comparable to those of the Californian with a better viability at weaning and slaughtering age.
\end{abstract}

Key words: Rabbit, performance, crossbreeding, heterosis.

\section{Introduction}

The study of the Algerian domestic rabbits' reproduction performances showed medium results, but the variability according to the individuals is important. The extent of their economical impact is as much expanded as the weight productivity, since their improvement is at the source of their numerical productivity increasing.

The growth performance shows that the animal

\footnotetext{
Corresponding author: Mefti Korteby Hakima, Ph.D., research field: animal production. E-mail: hakimakorteby@hotmail.fr.
}

belongs to the small size category. From 10 to 11 weeks old, an age meeting the standard slaughtering time in foreign countries, the domestic rabbit shows a live of 1.2-1.3 kg [1].

A weight considered unsatisfactory with non accepted carcasses by consumers, imposing then, a prolonged duration of the rearing period to offer heavier carcasses.

In Algeria the slaughtering age is 13 weeks, this lengthening involves deterioration risk of zootechnical ratios.

In pure breed, selection surely enables to eliminate non desirable characters then, to make uniform the 
zootechnic performances and besides to perform genetic progress on sought after criteria, but selection alone is not able to change the animal size. Genetic crossbreeding allows the modification when choosing suitable breeds or strains capable to meet this role, making profit of the genetic progress carried out on improvement breeds. The selection will actually become again subsequent step for crossbreeding.

The goal of this study refers to the complementarily use between the adaptation of the domestic rabbit to its native environment and the Californian's growth through a genetic crossbreeding of both populations.

The crossbreeding impact is analyzed through the reproduction and growth performances compared to the controls settled under similar conditions.

\section{Materials and Methods}

\subsection{Premises and Equipment}

The hutch is closed type, consisting of two maternity rooms, and fattening room. The conditions are not under controlled environment housing. The used rearing cages are of flat-deck type (one tier). Female cages are with nest boxes. Fattening cages are single or collective. Water automatic supply is provided through nipples assembled on a rigid pipe.

Feedstuff distributed is a granulate made of barley, corn, alfalfa, flour, wheat bran and a premix.

\subsection{Biological Material}

Three groups of rabbits consist of 10 females and two males added to each group, two male and females control batches belong to the same genetic type, one is domestic and the other is Californian, and both composed of rabbits breeders consist of 30 females and six males distributed as follows (father's genetic type is given first):

Batch L: two domestic males and 10 domestic females;

Batch C: two Californian males and 10 Californian females;

Batch $\mathrm{L} \times \mathrm{C}$ : two domestic males and 10
Californian females.

When reproduction started the mean female age is five months, and six months for males. The females used in this study are nulliparous. The balance male/female at matting is $1 / 5$.

The growth follow-up concerns 385 young rabbits from weaning until 13 weeks old.

\subsection{Rearing Behavior}

Mating is natural. The pregnancy diagnostic is made trough abdominal palpation at 12 days after positive copulation.

The reproduction rhythm is a semi intensive one, females are presented again at copulation 12 days post partum. Young small rabbits weaning is done at 35 days.

\subsection{Measures Carried out}

Breeders are weight when entering reproduction and at copulation. Females are weighed at parturition. Counting of the young small rabbits per litter born alive and weaned is carried out. The young rabbits are weighed from day 1 to day 21 , with empty stomach and after milk feeding.

\subsection{Calculated Parameters}

Born litter: size (BLS), alive (ALS) and weaned $($ WLS $)=$ small young rabbits number/parturition number.

Weight litter: born (BLW); alive (ALW) and weaned (WLW).

Individual weight of: one born (IWB), one alive (IWA) and one weaned (IWW) $=(B L W / B L S)$; (ALW/ALS) and (WLW/WLS).

Milk quantity/day $=($ litter weight after milk feeding - litter weight before milk feeding).

MDG or mean day gain of the small young rabbits during the first 21 days $(\mathrm{g} /$ day $)=$ (weight before milk sucking $J_{n}$ - weight before milk sucking $J_{n-1}$ ).

A new parameter is introduced $\mathrm{C}_{1}$, enabling to give value the day conversion of milk relatively to the 
mother weight at parturition.

$\mathrm{C}_{1}=($ milk quantity/day)/female weight at parturition) $\times 100$. Higher is this parameter, better is the conversion.

DMG (Daily mean growth) birth-weaning (g/day) = (Weight at 35 days - weight at birth)/35.

DMG (Daily mean growth) post weaning $=($ weight at week $n$ - initial weight $n-1) / 7$.

FCR (Feed conversion ratio or feed conversion ratio) = ingested quantity $(\mathrm{g}) / \mathrm{DMG}$.

The heterosis effect is calculated for the different parameters:

$\mathrm{H} \%=\left[\left(\mathrm{P}_{\mathrm{F} 1}-\mathrm{P}_{\mathrm{MP}}\right) / \mathrm{P}_{\mathrm{MP}}\right] / 100$.

$\mathrm{P}_{\mathrm{F} 1}$ : Mean performance of crossbred.

$\mathrm{P}_{\mathrm{MP}}$ : Mean performance of parents $\mathrm{A}$ and $\mathrm{B}$. $\mathrm{P}_{\mathrm{MP}}=$ $\left(\mathrm{P}_{\mathrm{A}}+\mathrm{P}_{\mathrm{B}}\right) / 2$.

\subsection{Statistical Analysis}

The calculated parameters of both batches are submitted to an Anova test trough the SPSS version Softwware 11.5.

\section{Results and Discussion}

\subsection{Breeders Performances and Mother Milk Production}

The performances results are grouped in table 1 .

Male and female breeders from the Californian genotype shows a more interesting weight compared to those of the domestic genotype. Females continue to gain weight from the reproduction beginning and copulation, in average $17 \%$ to $21 \%$ regardless of the genotype. From copulation until parturition, it is observed a light weight increasing of $3 \%$. That observation is in contradiction with Ref. [1] and Ref. [2], which confirm a female weight drop between these two events.

The positive effect of crossbreeding on the crossbred female fertility has been pointed out Hulot and Matheron since 1979 [3].

The milk production checking up during the 21 days shows any difference between the mother genotype and the crossbreeding effect. However the domestic female rabbits present a better milk production and ingested milk quantity level per young small rabbit/day.

The milk production of the letter female rabbits is comparable to these found by Zerrouki and Lebas [4] and Moumen et al. [5], respectively 2,180 $\mathrm{g}$ and 2,166 g.

A percentage of the relationship between the daily milk production and the female weight at parturition may indicate the best milk production.

It is obvious that more the parameter is high better is the daily conversion. Indeed, the feed conversion

Table 1 Reproduction performances linked to the breedersin crossed rabbits, domestic and californian controls.

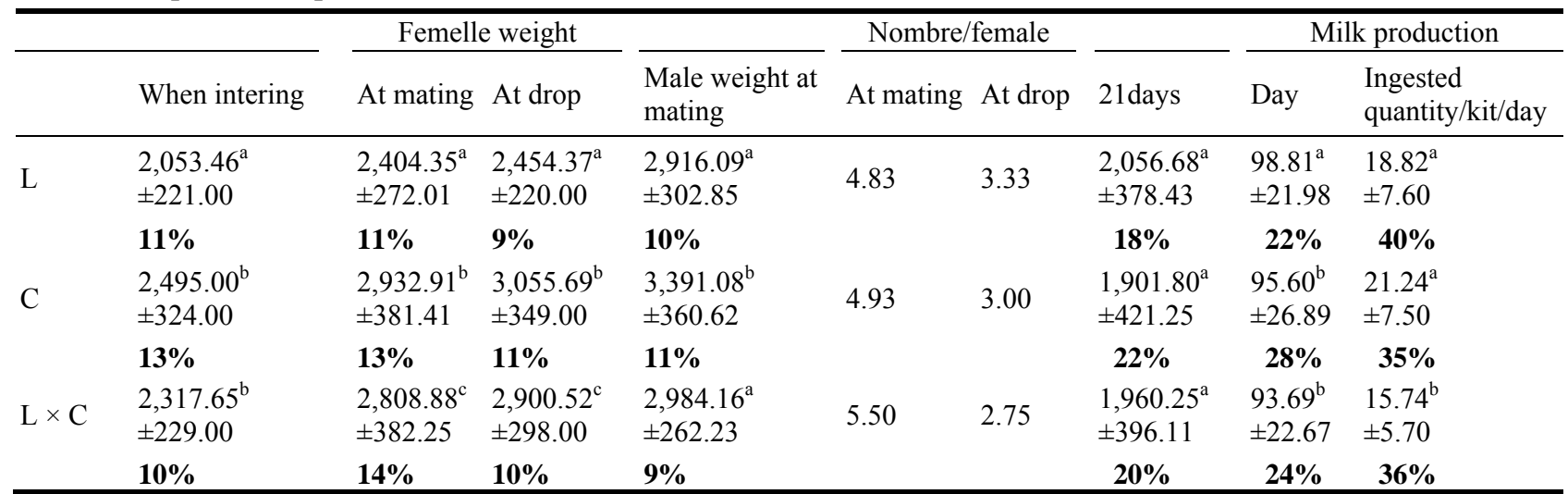

On the same column, means followed by a different letter are statistically incomparable at threshold $\alpha=5 \%$, the value between brackets represents the standard deviation, values in bold types [variation index $=($ standard deviation $/$ mean $) \times 100]$. L: Endemic Algerian rabbit, C: Californian rabbit. 
ratio value is four for the domestic female, three for the Californian and 3.19 for the $\mathrm{L} \times \mathrm{C}$ batch.

\subsection{Performances Linked to the Litter Size and Viability before and after Weaning}

The performances results are grouped in table 2 .

The Californian females crossbred with domestic males have an ameliorated alive litter at birth respectively with $9.43 \%$ and $16.34 \%$ compared to the parental mean.

This result is in accordance with Refs. [6-11], who evaluated the heterosis parameter between $4 \%$ and $21 \%$.

The prolificity of the domestic population is 6.7, when studied is close on those of domestic Mediterranean population, Gisa white, Baladi Red (Egyptian population) [12, 13] or Zemmouri (Marocan population) [14]. However, the crossbreeding effect involved a clear decreasing of the birth-weaning mortality rate which had positive repercussions on the weaned litter size and on weaning slaughtering mortalities. Remember that the crossbred can better bear the difficult raising conditions than the pure individuals.

The regression between born and weaned litter size is $20 \%$ on crossbred, $22 \%$ in the domestic, and $34 \%$ in the Californian, according to Ref. [15], results regression is $31 \%$ in observed, crossbred.

\subsection{Performances Linked to the Litter Weight and} before and after Weaning Growth

The performances results are grouped in table 3 .

The heterosis effect of the litter weight's characters are lesser important than those linked to litter number. Performances of crossbred are for the most of them comparable to those of the Californian mentioning. The weight litter born alive, the individual weight of the born young small rabbit and the post weaning feed conversion ratio. Generally the crossbred presents a better uniformity than the controls. The heterosis effect on the born alive liter size is respectively $10 \%$ and $16.75 \%$ and is just $2.57 \%$ for the same criteria at weaning. However, this $2.57 \%$ ù value is close to the found value of $3 \%$ by Ben Hamouda and Kennou 1990 [7], who had crossbred in HYLA males with a Tunisian domestic female population. The crossbred presents an individual weight at birth intermediate between this one of the parents without any heterosis effect appearance.

However, any individual weight increasing at birth may have positive consequences on the viability since negative genetical correlations have been pointed out by several studies [16-18]. A low decreasing of an alive and weaned rabbit individual observed comparatively to the parent mean.

Table 2 Performances linked to the litter size and to viability before and after weaning.

\begin{tabular}{lcccc}
\hline Caracter & $\mathrm{L}$ & $\mathrm{C}$ & $\mathrm{L} \times \mathrm{C}$ & Heterosis (\%) \\
\hline Size the born litter & $6.73^{\mathrm{a}} \pm 2.01$ & $6.82^{\mathrm{a}} \pm 2.44$ & $7.42^{\mathrm{a}} \pm 2.16$ & 9.43 \\
& $\mathbf{3 0 \%}$ & $\mathbf{3 6 \%}$ & $\mathbf{3 9 \%}$ & 16.34 \\
Size of the alive litter & $5.65^{\mathrm{a}} \pm 2,98$ & $5.6^{\mathrm{a}} \pm 3,09$ & $6.55^{\mathrm{a}} \pm 2,85$ & $\mathbf{4 4 \%}$ \\
& $\mathbf{5 3 \%}$ & $\mathbf{5 5 \%}$ & 13.6 & 21.93 \\
Death at birth \% & $19.20 \%$ & 23.24 & $5.95^{\mathrm{a}} \pm 1.97$ & $\mathbf{3 3 \%}$ \\
Size of the weaned litter & $5.25^{\mathrm{b}} \pm 2.26$ & $4.5^{\mathrm{c}} \pm 2,34$ & 19.81 & \\
& $\mathbf{4 3 \%}$ & $52 \%$ & 7.00 & \\
Mortality (birth - weaning)\% & 21.99 & 34.02 & 32.18 &
\end{tabular}

On the same column, means followed by a different letter are statistically incomparable at threshold $\alpha=5 \%$, the value between brackets represents the standard deviation, values in bold types [variation index $=($ standard deviation $/$ mean $) \times 100]$. L: Endemic Algerian rabbit, C: Californian rabbit. 

of the Domestic Rabbit (Algeria) $\times$ Californian

Table 3 Performances linked to the litter weight and to before and after weaning growth.

\begin{tabular}{|c|c|c|c|c|}
\hline Caracter & $\mathrm{L}$ & $\mathrm{C}$ & $\mathrm{L} \times \mathrm{C}$ & Heterosis $(\%)$ \\
\hline Born litter weight $(\mathrm{g})$ & $\begin{array}{l}325.88^{\mathrm{b}} \pm 89.00 \\
\mathbf{2 7 \%}\end{array}$ & $\begin{array}{l}373.26^{\mathrm{a}} \pm 114.00 \\
\mathbf{3 0} \%\end{array}$ & $\begin{array}{l}384.55^{\mathrm{a}} \pm 97.68 \\
\mathbf{2 5 \%}\end{array}$ & 10.01 \\
\hline Alive litter weight (g) & $\begin{array}{l}312.22^{b} \pm 103 \\
33 \%\end{array}$ & $\begin{array}{l}335.31^{\mathrm{b}} \pm 134.01 \\
\mathbf{4 0 \%}\end{array}$ & $\begin{array}{l}378.00^{\mathrm{a}} \pm 101,58 \\
\mathbf{2 7 \%}\end{array}$ & 16.75 \\
\hline Weaning litter weight $(\mathrm{g})$ & $\begin{array}{c}2,400.00^{\mathrm{a}} \pm 1039.00 \\
\mathbf{4 3 \%}\end{array}$ & $\begin{array}{c}2,279.17^{\mathrm{a}} \pm 1113.00 \\
\mathbf{4 9 \%}\end{array}$ & $\begin{array}{l}2,565.56^{\mathrm{a}} \pm 734.00 \\
\mathbf{2 9 \%} \%\end{array}$ & 2.57 \\
\hline Individual weight of one born & $\begin{array}{l}49.42^{b} \pm 8.50 \\
\mathbf{1 7 \%}\end{array}$ & $\begin{array}{l}56.36^{\mathrm{a}} \pm 7.70 \\
14 \%\end{array}$ & $\begin{array}{l}54.25^{\mathrm{a}} \pm 8.50 \\
\mathbf{1 6 \%}\end{array}$ & 2.57 \\
\hline Individual weight of one alive & $\begin{array}{l}51.40^{b} \pm 10.3 \\
20 \%\end{array}$ & $\begin{array}{l}57.79^{\mathrm{a}} \pm 8.00 \\
14 \%\end{array}$ & $\begin{array}{l}53.82^{\mathrm{a}} \pm 8.50 \\
16 \%\end{array}$ & - \\
\hline Individual weight of one weaned & $\begin{array}{c}475.58^{\mathrm{b}} \pm 110.00 \\
\mathbf{2 3 \%}\end{array}$ & $\begin{array}{l}502.94^{\mathrm{a}} \pm 109.09 \\
\mathbf{2 2 \%}\end{array}$ & $\begin{array}{l}487.68^{\mathrm{a}} \pm 118.05 \\
\mathbf{1 9 \%}\end{array}$ & - \\
\hline DMG (birth-weaning) & $\begin{array}{l}12.17^{\mathrm{a}} \pm 3.50 \\
\mathbf{2 9 \%}\end{array}$ & $\begin{array}{l}12.75^{\mathrm{a}} \pm 5 \\
39 \%\end{array}$ & $\begin{array}{l}12.34^{\mathrm{a}} \pm 3.00 \\
\mathbf{2 4 \%}\end{array}$ & 0.90 \\
\hline DMG (weaning-13th weeks) & $\begin{array}{l}20.24^{\mathrm{a}} \pm 3.00 \\
15 \%\end{array}$ & $\begin{array}{l}23.03^{\mathrm{a}} \pm 5.00 \\
22 \%\end{array}$ & $\begin{array}{l}23.00^{\mathrm{b}} \pm 4.00 \\
17 \%\end{array}$ & 11.00 \\
\hline FRC (weaning-13th weeks) & $\begin{array}{l}4.07^{\mathrm{a}} \pm 1.03 \\
25 \%\end{array}$ & $\begin{array}{l}3.71^{\mathrm{b}} \pm 1.00 \\
27 \%\end{array}$ & $\begin{array}{l}3.49^{\mathrm{b}} \pm 1.01 \\
\mathbf{2 9 \%}\end{array}$ & 10.00 \\
\hline Weight at 13 th weeks & $\begin{array}{c}1,609.09^{\mathrm{a}} \pm 256.27 \\
\mathbf{1 6 \%}\end{array}$ & $\begin{array}{c}1,793.63^{\mathrm{b}} \pm 279.61 \\
\mathbf{1 6 \%}\end{array}$ & $\begin{array}{c}1,775.83^{b} \pm 241.26 \\
\mathbf{1 4 \%}\end{array}$ & 7.00 \\
\hline
\end{tabular}

On the same column, means followed by a different letter are statistically incomparable at threshold $\alpha=5 \%$, the value between brackets represents the standard deviation, values in bold types (variation index $=$ [standard deviation/mean $] \times 100]$, DMG: daily mean gain (g/day); FCR: feed conversion ratio, 13 weeks represents the slaughtering age. L: Endemic Algerian rabbit, C: Californian rabbit

The daily mean feed gain pre-weaning and post weaning are comparable to the three batches, in spite of an ingested milk level definitely lower in the crossbred young small rabbits.

A better milk production would have enabled more important expression of the character. Indeed a strong positive correlation of 0.9 and 0.95 between milk production and young small rabbits mean daily gain under the mother is noted respectively [19].

The post weaning mean daily gain is comparable between the crossbred and the Californian but better than the domestic one from which an heterosis effect of $+17 \%$. The feed conversion ratio is improve by $+10 \%$ comparatively to the parents.

The weight at 13 weeks (specifically slaughtering age in Algeria) presents an heterosis effect of 5.5\%.

The post weaning growth performance shows that the crossbred genotype become highly closes of the pure Californian genotype, with an advantage materialized on the crossbred viability.

\section{Conclusion}

The domestic rabbit presents an adaptation to its nature environment, but its low performances make him uninteresting for growers.

The Californian genotype presents better zootechnical performances but its viability is low under Algerian rearing conditions.

The genetic crossbreeding between the two genotypes shows positive heterosis effect specially for the growing zootechnicl parameters making him close of the Californian with a clear advantage on viability, making obvious the crossbred resistance to the difficult rearing environment conditions through the hybrid vigor.

The numerical and weighting productivity are improved through the crossbreeding effect. The feed nutritive value skilling would make possible a better 
expression of the whole improved characters.

\section{Acknowledgments}

We would like to thank the officials, the engineer, the veterinary, students and workers in the experimental station of the university Saad DAHLAB Blida, for their valuable service for the good start of the experimental protocols.

\section{References}

[1] H. Mefti Korteby, R. Kaidi, S. Sid, O. Daoudi, Growth and reproduction performance of the Algerian endemic rabbit, European Journal of Scientific Research 40 (1) (2010) 132-143.

[2] G. Milisitis, R. Romvari, A. Dalle Zotte, Z. Szendro, Non invasive study in body composition in rabbit during pregnancy using X-ray computerized tomography, Ann. Zootech. 48 (1) (1999) 25-34.

[3] F. Hulot, G. Matheron, Effet du genotype: de l'âge et de la saison sur les composantes de la reproduction chez la lapine, Ann. Genet. Sel. Anim. 13 (2) (1981) 131-150. (in French)

[4] N. Zerrouki, F. Lebas, Evaluation of milk production of an Algerian local rabbit population raised in the Tizi Ouzou area (Kabylia), World Rabbit Sci. 13 (2005) 3947.

[5] S. Moumen, H. Ain Baziz, S. Temim, Effet du rythme de reproduction sur les performances zootechniques des lapines de population locale Algérienne (Oryctolagus cuniculus), Livestock Research for Rural Development 21 (8) (2009). (in French)

[6] J.M. Brun, R. Rouvier, Effets génétiques sur les caractères des portées issues de trois souches de lapins utilisées en croisement, Rev. Génétique Sélection Evolution 16 (3) (1984) 367-384. (in French)

[7] M. Ben Hamouda, S. Kennou, Croisement de lapins locaux avec la souche Hyla: resultats des performances de reproduction et de croissance en première generation, Rev. Option Méditerranéennes Série Séminaires 8 (1990)103-108. (in French)

[8] A.A. Al Saef, M.H. Khalil, A.H. Al Homidan, S.N. Al Doubaib, S.N. Al Soubayl, M.L. Garcia, et al., Crossbreeding effects for litter and lactation traits in a Saudi project to development lines of rabbits suitable for hot climates, Livestock science 118 (3) (2008) 238246.
[9] J.M. Brun., G. Saleil, Une estimation en fermes de l'hétérosis sur les performances entre souches INRA A2066 et A1077, 5ème JRC, 1994, pp. 203-210. (in French)

[10] R. Nofal, Z.S. Szendro, A. Kenessey, J.E. Jensen, Cross breeding effects on carcass traits at 12 weeks of age in Pannon and Danish White rabbits and their reciprocal crosses, Proc. 8th W.R.C, Puebla, Mexico, 2004, pp. 114-120.

[11] A. Ouyed, F. Lebas, M.L. efranois, J. Rivest, Performances de reproduction de lapines de races Néo Zélandais Blanc, Californien et Géant du Bouscat ou croisées en élevage assaini au Quebec, in: Proc. 12ème Journées de Recherches Cunicole, INRA-ITAVI, Le Mans, France, 2007, pp. 149-152. (in French)

[12] M.H. Khalil, Rabbit genetic resources of Egypt, Animal Genetic Resources Information 26 (1999) 95-110.

[13] A.S. Abdel Azeem, A.M. Abdel Azeem, A.A. Darwish, E.M. Omara, Litter traits in four pure breeds of rabbits and their crosses under prevailing environmental conditions of Egypt, 5th Inter. con. on Rabbit Prod. in Hot. Clim. Hurghada, Egypt, 2007, pp. 39-51.

[14] A. Barkok, T. Djaouzi, The Zemmouri rabbits (Marocco), in rabbit genetic ressources in Mediterranean countries, Rev. Option Méditerranéennes Série B 38 (2002) 179-185.

[15] Y.M.K. Youssef, M.H. Khalil, E.A. Afifi, A.M.E. El Raffa, M. Zahaeds, Heritability and non genetic factors for lifetime production traits in Newzeland White rabbits, 2000.

[16] S. Sid, Etude des paramètres génétiques et zootechniques sur les critères de reproduction chez le lapin local (Oryctolagus cuniculus), Mémoire d'ingénieur, Sciences agronomiques, University Saad DAHLAB BLIDA, ALGERIE, 2005. (in French)

[17] D. Saidj, Performances de reproduction et paramètres génétiques d'une lignée maternelle d'une population lapin local selectionnée en G0, Mémoire de Magister, ENV Alger, 2006.

[18] T. Chaou, Etude des paramètres zootechniques et génétiques d'une lignée paternelle sélectionnée et de sa descendance du lapin local (Oryctolagus cuniculus), Mémoire de Magister, École national supérieure vétérinaire, Algeria, 2006. (in French)

[19] L. Fortun-Lamothe, F. Sabater, Estimation de la production laitière des lapines à partir de la croissance des lapereaux, 10ème JRC, Paris, 2003, pp. 69-72. (in French) 